\title{
A histochemical study of the effect of danazol and oestradiol- $17 \beta$ on steroidogenic activity in testis and epididymis of the gerbil, Tatera indica
}

\author{
M. V. Chandrakala and H. B. Devaraj Sarkar \\ Department of Zoology, University of Mysore, Manasagangotri, Mysore-570 006, India
}

\begin{abstract}
Summary. Danazol $(4 \mathrm{mg} /$ day/animal $)$ and oestradiol- $17 \beta(100 \mu \mathrm{g} / \mathrm{day} /$ animal $)$ were administered subcutaneously for 22 and 15 days respectively. The testis and epididymis were histochemically analysed for steroid dehydrogenases, NADHdiaphorase, glucose 6-phosphate dehydrogenase activity and lipids. Both steroids significantly reduced the weights of the testis and other accessory reproductive organs. The activities of $\Delta^{5}-3 \beta$ - and $17 \beta-$ HSD were markedly reduced in the seminiferous epithelium and interstitial cells of the testis. Sudanophilic lipids accumulated in the seminiferous tubules and the interstitium. Oestradiol generally had a greater effect than did danazol, but both probably affect the testicular function by inhibiting steroidogenesis.
\end{abstract}

\section{Introduction}

Danazol, a heterocyclic steroid (17 $\alpha$-pregna-2,4-dien-20-ynol2,3-d]isoxazol-17/3-ol), is reported to be antigonadotrophic and without antiprogestational activity (Franchimont \& Cramillon, 1977). It has therefore been recommended as a contraceptive drug for both men and women (Colle \& Greenblatt, 1976) although at present it is clinically used only in cases of endometriosis (Dmowski, 1979). The effect of danazol on the pituitary and male reproductive tract has been studied in many mammals (Sherins, Gandy, Thorslund \& Paulsen, 1971; Dixit \& Lohiya, 1975; Franchimont \& Cramillon, 1977). In-vitro studies have suggested that the drug has a direct effect on testicular steroidogenesis (Barbieri et al., 1977). Oestrogens also have anti-androgenic properties in the male, causing azoospermia and reduction of plasma testosterone levels (Verjans, de Jong, Cooke, van der Molen \& Eik-Nes, 1974; Bartke, Williams \& Dalterio, 1977; Hunt, Saksena \& Chang, 1979). The present study describes the effect of danazol and oestradiol- $17 \beta$ on the histochemistry of the testis and epididymis of the gerbil.

\section{Materials and Methods}

Sexually mature male gerbils (Tatera indica) weighing more than $120 \mathrm{~g}$ were collected from the fields and divided into four groups. Group 1 was treated with danazol (the gift of Dr N. K. Lohiya. Department of Zoology, University of Rajasthan Jaipur, India), $4 \mathrm{mg} /$ day/animal subcutaneously in olive oil for 22 days. Group 2 received only the vehicle for 22 days. Gerbils in Group 3 received s.c. injections of oestradiol-17 (E. Merck, Germany), $100 \mu \mathrm{g} /$ day/animal in olive oil for 15 days. Group 4 was treated with vehicle only for the same duration. All the animals were kept under laboratory conditions, fed with rat chow and given water ad libitum. 
They were killed by cervical dislocation $24 \mathrm{~h}$ after the last injection and the reproductive organs (testis, epididymis, seminal vesicle, ventral prostate and Cowper's glands) were dissected out. freed from fat, weighed on a torsion balance to the nearest $1 \mathrm{mg}$ and fixed in Bouin-Hollande (6.25 g copper acetate, $25 \mathrm{ml} 40 \%$ formaldehyde, $2.5 \mathrm{ml}$ glacial acetic acid, $5 \mathrm{~g}$ picric acid, 250 $\mathrm{ml}$ distilled water). Paraffin wax sections $(6 \mu \mathrm{m})$ were cut and stained in haematoxylin and eosin for histological observations. One of the testes and epididymides from each animal was frozen immediately at $-20^{\circ} \mathrm{C}$. Sections were cut $(16 \mu \mathrm{m})$ in a cryostat maintained at $-20^{\circ} \mathrm{C}$. Unfixed, air-dried sections were incubated at $37^{\circ} \mathrm{C}$ for $1 \mathrm{~h}$ in appropriate media containing different substrates, co-factors and tetrazolium salt. The $\Delta^{5}-3 \beta$ - and $17 \beta$-hydroxysteroid dehydrogenases (HSD) were localized as described by Baillie, Ferguson \& Hart (1966). Parallel cryostat sections were incubated for glucose 6-phosphate dehydrogenase and NADH-diaphorase as described by Pearse (1972). Sudan Black B was used to localize lipids (Pearse, 1972). Suitable control tests were carried out by incubating cryostat sections in a medium containing no substrates and/or co-factor (NAD). After incubation, sections were washed, fixed in $10 \%$ neutral formalin $(40 \%$ formaldehyde) and mounted in PVP aqueous mounting medium or glycerol jelly. The pattern of distribution and intensity of enzyme activities in the seminiferous epithelium and interstitium of the testis and epithelium and luminal contents of the epididymis were visually assessed on a 4-point scale ranging from nil $(-)$ to intense $(+++)$.

Table 1. Effect of danazol and oestradiol- $17 \beta$ on mean \pm s.e.m. organ weights $(\mathrm{mg})$ of the gerbil

\begin{tabular}{|c|c|c|c|c|}
\hline Organs & $\begin{array}{l}\text { Group } 2 \\
\text { (olive oil } \\
\text { control) }\end{array}$ & $\begin{array}{c}\text { Group 1 } \\
\text { (danazol) }\end{array}$ & $\begin{array}{l}\text { Group 4 } \\
\text { (olive oil } \\
\text { control) }\end{array}$ & $\begin{array}{l}\text { Group } 3 \\
\text { (oestradiol) }\end{array}$ \\
\hline Testis $\dagger$ & $1134.4 \pm 78.9$ & $933.5 \pm 91.5$ & $1034.5 \pm 80 \cdot 8$ & $581.4 \pm 38.8^{* *}$ \\
\hline Epididymis $†$ & $386.3 \pm 60.2$ & $209.8 \pm 20.3^{*}$ & $306.3 \pm 24.8$ & $160.4 \pm 12.9^{* *}$ \\
\hline Vas deferens $†$ & $89.8 \pm 5.7$ & $33.5 \pm 2.5^{* * *}$ & $86 \cdot 5 \pm 4.7$ & $29.9 \pm 3 \cdot 0^{* * *}$ \\
\hline Seminal vesicle $†$ & $301 \cdot 5 \pm 46 \cdot 2$ & $161.9 \pm 16.7^{*}$ & $347 \cdot 5 \pm 26 \cdot 0$ & $182.2 \pm 27.0^{* *}$ \\
\hline Ventral prostate & $81.7 \pm 7.3$ & $57.2 \pm 5.2^{*}$ & $81.7 \pm 7.3$ & $41.9 \pm 5 \cdot 2^{* *}$ \\
\hline Cowper's gland & $48 \cdot 6 \pm 3 \cdot 9$ & $33 \cdot 0 \pm 4 \cdot 8^{*}$ & $48 \cdot 6 \pm 3 \cdot 8$ & $27.9 \pm 1.9^{* *}$ \\
\hline
\end{tabular}

+ Only one organ, the right.

Values significantly different from respective control value: ${ }^{*} P<0.05,{ }^{* *} P<0.01,{ }^{* * *} P<0.001$.

Table 2. Localization of $\Delta^{5}-3 \beta$ - and $17 \beta$-HSD activity in the testis and epididymis of gerbils, treated with olive oil (Groups 2 and 4 combined), danazol (Group 1) and oestradiol-17 (Group 3)

\begin{tabular}{|c|c|c|c|c|c|c|c|c|c|c|c|c|}
\hline \multirow[b]{3}{*}{ Tissue } & \multicolumn{6}{|c|}{$\Delta^{s}-3 \beta-H S D$} & \multicolumn{6}{|c|}{$17 \beta-H S D$} \\
\hline & \multicolumn{3}{|c|}{ Pregnenolone } & \multicolumn{3}{|c|}{ DHA } & \multicolumn{3}{|c|}{ Oestradiol-17 $\beta$} & \multicolumn{3}{|c|}{ Testosterone } \\
\hline & $2+4$ & 1 & 3 & $2+4$ & 1 & 3 & $2+4$ & 1 & 3 & $2+4$ & 1 & 3 \\
\hline \multicolumn{13}{|l|}{ Testis } \\
\hline Seminiferous epithelium & ++ & - & - & ++ & - & - & ++ & + & - & ++ & + & - \\
\hline Interstitium & +++ & + & + & +++ & + & + & +++ & + & + & +++ & + & + \\
\hline \multicolumn{13}{|l|}{ Epididymis } \\
\hline \multicolumn{13}{|l|}{ Caput } \\
\hline Epithelium & ++ & ++ & + & ++ & + & + & ++ & ++ & + & t+ & ++ & + \\
\hline Lumen & + & + & - & + & + & - & + & + & - & + & + & - \\
\hline \multicolumn{13}{|l|}{ Corpus } \\
\hline Epithelium & t+ & ++ & + & ++ & + & + & ++ & ++ & + & ++ & ++ & + \\
\hline Lumen & + & + & - & + & + & - & + & + & - & + & + & - \\
\hline \multicolumn{13}{|l|}{ Cauda } \\
\hline Epithelium & +++ & ++ & + & +++ & ++ & + & +++ & ++ & + & $+t+$ & ++ & + \\
\hline Lumen & ++ & + & - & ++ & + & - & ++ & + & - & ++ & + & - \\
\hline
\end{tabular}

,- nil; + , faint; ++ , moderate; +++ , intense.

Tissues of Groups $2+4$ did not show any difference in their histochemical activity. 

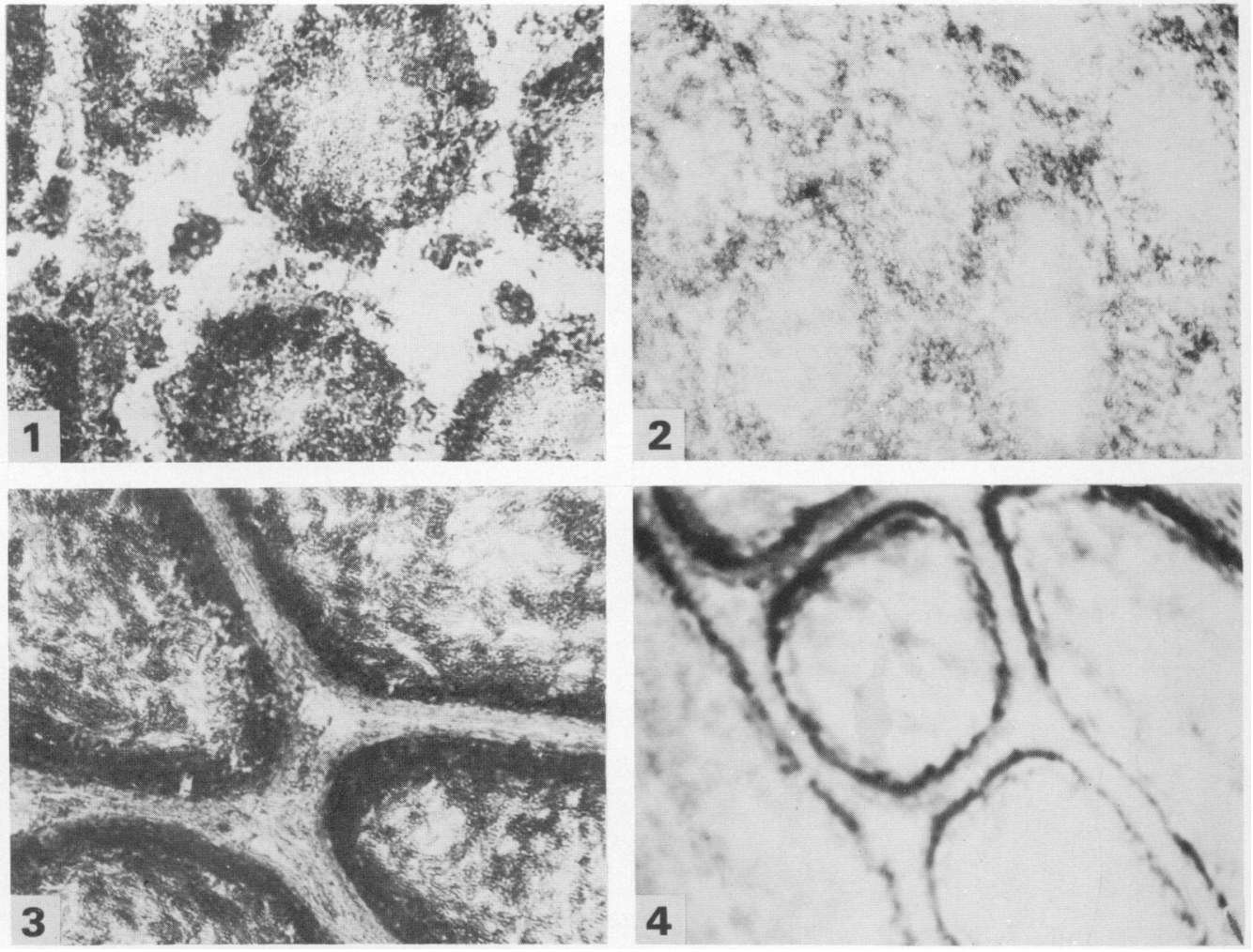

Fig. 1. Localization of strong $17 \beta$-HSD (testosterone as the substrate) activity in the seminiferous epithelium and interstitial cells of a control gerbil. $\times 75$.

Fig. 2. Localization of weak 17 $\beta$-HSD activity (substrate: testosterone) in the seminiferous epithelium and interstitial cells of the testis after danazol treatment. $\times 75$.

Fig. 3. Localization of $\Delta^{5}-3 \beta$-HSD (substrate: DHA) activity in the epithelium and luminal contents of the cauda epididymidis of a control gerbil. $\times 75$.

Fig. 4. Localization of a faint $\Delta^{5}-3 \beta-H S D$ (substrate: DHA) activity in the epithelium only of the cauda epididy midis after oestradiol- $17 \beta$ treatment. $\times 75$. 


\section{Results}

All the organs were significantly lighter after danazol $(P<0.05)$ or oestradiol- 17$\} 3(P<0.01)$ treatment (Table 1). Danazol and oestradiol treatment completely abolished the activity of $\Delta^{3}-3 \beta$-HSD from the seminiferous tubules and reduced the activity considerably in the interstitium of the testis when compared to that of control animals (PI. 1, Figs 1 and 2). The activity of both HSDs in the epididymis was more affected by oestradiol than by danazol (Table 2). The enzyme profile was unaffected by danazol, but oestradiol caused a reduced activity of NADH-diaphorase (Table 3). The activity of glucose 6-phosphate dehydrogenase was reduced in the testis but unaltered in the epididymis (Table 3). Lipids accumulated in the testis and epididymis in the treated animals and were more pronounced in the interstitium of the testis and the cauda epididymidis. Enzyme activity in both the epithelium and the luminal content of the epididymis was suppressed by oestradiol treatment, compared with controls (Pl. 1, Figs 3 and 4).

Table 3. Localization of NADH-diaphorase, glucose 6-phosphate dehydrogenase and lipids in the testis and epididymis of gerbils, treated with olive oil (Groups $2+4$ ), danazol (Group 1) and oestradiol$17 \beta$ (Group 3)

\begin{tabular}{|c|c|c|c|c|c|c|c|c|c|}
\hline \multirow[b]{2}{*}{ Tissue } & \multicolumn{3}{|c|}{ NADH-diaphorase } & \multicolumn{3}{|c|}{ G 6-PDH } & \multicolumn{3}{|c|}{ Lipids } \\
\hline & $2+4$ & 1 & 3 & $2+4$ & 1 & 3 & $2+4$ & 1 & 3 \\
\hline \multicolumn{10}{|l|}{ Testis } \\
\hline $\begin{array}{l}\text { Seminiferous } \\
\text { epithelium }\end{array}$ & ++ & ++ & + & + & - & + & - & + & + \\
\hline Interstitium & +++ & +++ & ++ & ++ & ++ & + & ++ & ++ & ++ \\
\hline \multicolumn{10}{|l|}{$\begin{array}{l}\text { Epididymis } \\
\text { Caput }\end{array}$} \\
\hline Epithelium & +++ & +++ & + & ++ & ++ & ++ & - & - & + \\
\hline Lumen & + & + & - & + & - & - & - & - & - \\
\hline \multicolumn{10}{|l|}{ Corpus } \\
\hline Epithelium & +++ & +++ & + & ++ & ++ & ++ & - & - & + \\
\hline Lumen & + & + & - & + & - & - & - & - & - \\
\hline \multicolumn{10}{|l|}{ Cauda } \\
\hline Epithelium & +++ & +++ & ++ & ++ & ++ & ++ & - & + & + \\
\hline Lumen & ++ & ++ & - & + & + & - & - & - & - \\
\hline
\end{tabular}

- , nil; + , faint; ++ , moderate; +++ , intense.

Tissues of Groups $2+4$ did not show any difference in their histochemical activity.

\section{Discussion}

It is well established that interstitial cells and Sertoli cells are sites of steroidogenesis in the mammalian testis (Bell \& Lacy, 1974). The histochemical localization of steroidogenic enzyme activity and lipids in tissue sections has been taken to indicate the sites of steroid metabolism (Baillie, Ferguson \& Hart, 1966; Woods \& Domm, 1966). Therefore, the decreased activity of HSDs, accumulation of lipids in the testis and concomitant reduction in weights of androgen-dependent organs in danazol- and oestradiol-treated gerbils clearly suggests a reduction in steroid production in the testis. Barbieri et al. (1977) have found that danazol inhibits various enzymes involved in steroid synthesis including $\Delta^{5}-3 \beta$ - and 17 $\beta$-HSDs in rat testis and hamster ovaries in vitro. Oestrogen administration is reported to reduce testosterone synthesis in vitro in the testis of rats and mice (Bartke et al., 1977). Diethylstilboestrol treatment inhibits $17 \beta$-HSD activity in mouse testis (Samuels, Uchikawa, Zain-el-abedin \& Huseby, 1969), but Kaartinen, Laukkanen \& Saure (1971) also noted a reduction in the activity of $\Delta^{5}-3 \beta$-HSD when a higher concentration of oestradiol was added to the medium in vitro. Our study with gerbils indicates that both these enzymes were inhibited in testis exposed to one dose level. 
The mammalian epididymis and epididymal spermatozoa are also able to metabolize steroid hormones (McGadey, Baillie \& Ferguson, 1966; Djøseland, 1976). The reduced HSD activity in these sites after oestradiol treatment suggests a direct effect on the epididymis which is probably due to binding to oestrogen receptors (Djøseland, 1976; Danzo, Eller, Judy, Trautman \& Orgebin-Crist, 1975). The unaltered histochemical profile of the epididymis in danazol-treated gerbils may be due to the weak androgenic property of this drug (Colle \& Greenblatt, 1976).

We thank Professor M. R. Rajasekarasetty for his encouragement and Mr B. M. Sekharappa and Mr G. R. Shivakumar for assistance. M.V.C. is grateful to the U.G.C. (New Delhi, India) for the award of a research fellowship.

\section{References}

Baillie, A.H., Ferguson, M.M. \& Hart, D.McK. (1966) Steroid Histochemistry, p. 5. Academic Press, London.

Barbieri, R.L., Canick, J.A., Mafris. A., Todd, R.B.. Davies, I.J. \& Ryan. K.J. (1977) Danazol inhibits steroidogenesis. Fert. Steril. 28, 809-913.

Bartke, A., Williams, K.I.H. \& Dalterio, S. (1977) Effects of estrogens on testicular testosterone production in vitro. Biol. Reprod. 17, 645-649.

Bell, J.B.C. \& Lacy, D. (1974) Studies on the structure and function of the mammalian testis. V. Steroid metabolism by isolated interstitium and seminiferous tubules of the human testis. Proc. R. Soc. B 186, 99-120.

Colle, M.L. \& Greenblatt, R.B. (1976) Contraceptive properties of danazol. J. Reprod. Med. 17, 98-102.

Danzo, B.T., Eller, B.C., Judy, C.A.. Trautman, J.R. \& Orgebin-Crist, M.C. (1975) Estradiol binding in cytosol from epididymides of immature rabbits. Molec. cell. Endocr. 2, 91-105.

Dixit, V.P. \& Lohiya, N.K. (1975) Effects of danazol on the pituitary-gonadal axis in male gerbils and mice. Fert. Steril. 26, 68-73.

Djøseland, O. (1976) Androgen metabolism by rat epididymis. 3. Effect of castration and treatment with anti-androgens. Steroids 27, 47-64.

Dmowski, W.P. (1979) Endocrine properties of danazol. Fert. Steril. 31, 237-251.

Franchimont, P. \& Cramillon, Cl. (1977) The effect of danazol on anterior pituitary function. Fert. Steril. 28, 814-817.
Hunt, D.M., Saksena, S.K. \& Chang, M.C. (1979) Effects of estradiol-17B on reproduction in adult male rats. Archs Androl. 2, 129-133.

Kaartinen, E., Laukkanen, M. \& Saure, A. (1971) Metabolism of dehydroepiandrosterone by rat testicular homogenates; kinetic study at different temperatures; direct effect of $17 \beta$-estradiol. Acta endocr., Copenh. 66, 50-64.

McGadey, J., Baillie, A.H. \& Ferguson, M.M. (1966) Histochemical utilization of hydroxysteroids by the hamster epididymis. Histochemie 7, 211-217.

Pearse, A.G.E. (1972) Histochemistry. Theoretical and Applied 3rd edn, Vol. Il, p. 1342. Churchill Livingstone, Edinburgh.

Samuels, L.T., Uchikawa, T., Zain-el-abedin, M. \& Huseby, R.B. (1969) Effect of diethylstilbestrol on enzymes of cryptorchid mouse testis of balb/c mice. Endocrinology 85, 96-102.

Sherins, R.J., Gandy, H.M., Thorslund, T.W. \& Paulsen, C.A. (1971) Pituitary and testicular function studies. I. Experience with a new gonadal inhibitor, $17 \alpha$ pregn-4-en-20-yno-(2,3-d) isoxazol-17 $\beta$-ol (danazol). J. clin. Endocr. Metab. 32, 522-531.

Verjans, H.L., de Jong, F.H., Cooke, B.A., van der Molen, H.J. \& Eik-Nes, K.B. (1974) Effects of oestradiol benzoate on pituitary and testis function in the normal adult male rats. Acta endocr., Copenh. 77, $636-642$.

Woods, J.E. \& Domm, L.V. (1966) Histochemical identification of the androgen-producing cells in the gonads of the domestic fowl and albino rat. Gen. comp. Endocr. 7, 559-570. 